\title{
An Efficient Framework for Online Dealer Management Portal Using Sap Abap Web-Dynpro
}

\author{
Manisha Madhwani ${ }^{1}$, R. Roseline Mary ${ }^{1}$ \\ ${ }^{\text {I}}$ (Department of Computer Science, Christ University, India)
}

\begin{abstract}
Most of the businesses need strategy for sales and distribution of their products. In order to have massive distribution of product the manufacturers have to first reach out the dealers to promote their products. The selling process comprises multiple business process such as warranty and claim of a material produced from the manufacturer. However, various business processes involved can be customized for all the various products. This investigative study proposes an efficient framework for online dealer management portal using SAP Abap Web-Dynpro.
\end{abstract}

Keywords - SAP, ERP, Abap Web-Dynpro, Dealer Portal

\section{INTRODUCTION}

Most of the businesses require strategic management for their dealers (or the indirect end-customers) in order to gain from the available software solutions. To facilitate a manufacturer with his $n$-dealer interaction, the dealer portal is designed. The "Dealer Portal" is a web-based application which allows the manufacturer to upload and manage his/her stock online. The Portal provides access to all the key products, warranty, services, auction and bidding for maximizing sales in the market. The "Dealer Portal" helps extend business experience and creates opportunities to aid the business grow in size by maximizing sales and commissions.

SAP is abbreviated as Systems Applications and Products. It creates a common centralized database for all the applications running in an organization. The application has been assembled in such a versatile way that it handles all the functional departments within the organization. Sap's applications are built around R/3 system which provides the functionality to manage product operations, cost accounting, assets, materials and personnel [1]. SAP ERP (Enterprise Resource Planning) is one of the oldest and most famous solutions for enterprise resource planning. The "Dealer Portal" is a proposed SAP ERP solution providing implementation majorly of SD (Sales \& Distribution) module.

\section{DEALER MANAGEMENT}

Dealer Management relates to strategic approach where a manufacturer seeks to optimize his/her gain from the enterprise solution in an easy, efficient and economic way. The distribution of material produced at his/her end across dealers including scope of warranty, claim, service and bidding as per need of each manufacturer is proposed. It is a B2B application where not only the product's dealer but also its tertiary dealers are managed in a manner to keep track the distribution of a production till the end-customer.

The dealer portal facilitates the users with the following features:

1. Search for other dealers/partners online by type, name, geography solution and/or market

2. Identify partners by products and services

3. Communicate and collaborate with partners online

4. Place online orders and up to invoice generation

5. Collaboration tool-create, post and/or respond to queries using the chat \& messaging tool [2].

\section{FRAMEWORK}

In this section the framework of proposed SDP model are discussed.

\section{Definition}

(i) Tertiary Dealers: Tertiary dealers are such dealers falling in category of sub-dealers who are just able to reach the product to the end customer but not the warranty, claim, etc.

(ii) Sales at Back-Date: When the sales are to be done at a back-date or a previous date as record of those sales doesn't exist then it becomes sales at back-date.

\section{Proposed SDP Model}

The SDP model works using design of Model-View-Controller (MVC). The model consists of application data, business rules, logic, and functions. A view can be any output representation of data, such as a chart or a diagram. Multiple views of the same data are possible, such as a pie chart for management and a 
tabular view for accountants. The controller mediates input, converting it to commands for the model or the view. The central ideas behind MVC are code reusability and separation of concerns [3].

However, its framework pursues SAP Sales \& Distribution module for proposed project SDP model. The flow or the framework of the model is depicted in Fig. 1 [4]

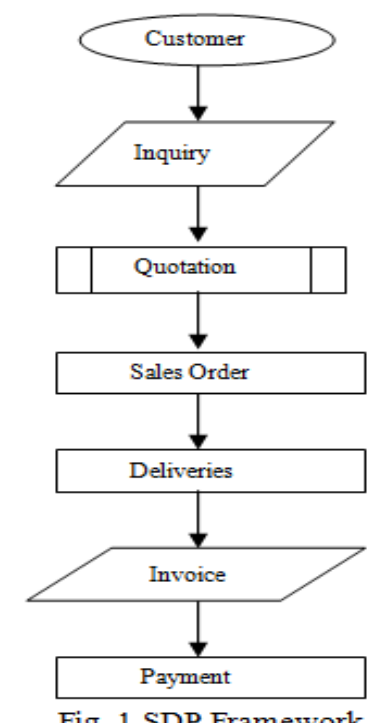

\section{ARCHITECTURE DESIGN}

This proposed scheme makes use of SAP ABAP Web-Dynpro to develop and publish the dealer portal. The scheme is cost effective, simple and easy to implement. The client or the dealer just logs in to the portal providing username and password on his/her browser which is served at SAP server and corresponding HTML is generated as a response to the request. Working of SDP model has been generalized in Fig. 2 below:

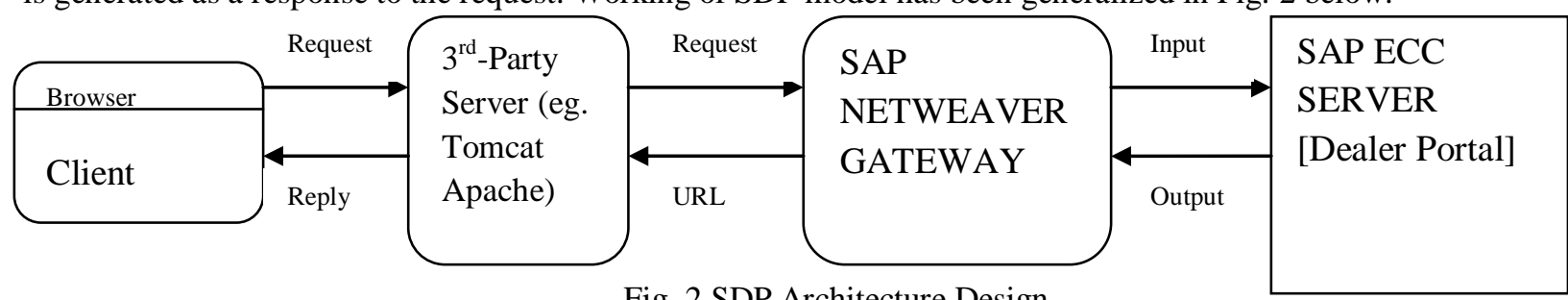

Fig. 2 SDP Architecture Design

\section{Sales}

\section{AlgorithM}

In case of sales the customer is either an end-customer or a tertiary. If a customer exists then he has to be searched with the pan-card number or the mobile number or any unique number lest the new customer record has to be created with new sales data. The Dealer must upload excel file for each material sold details also if any, tertiary dealers under him must provide dealer with the excel file. In below Fig. 3, algorithm for product sales is explained.

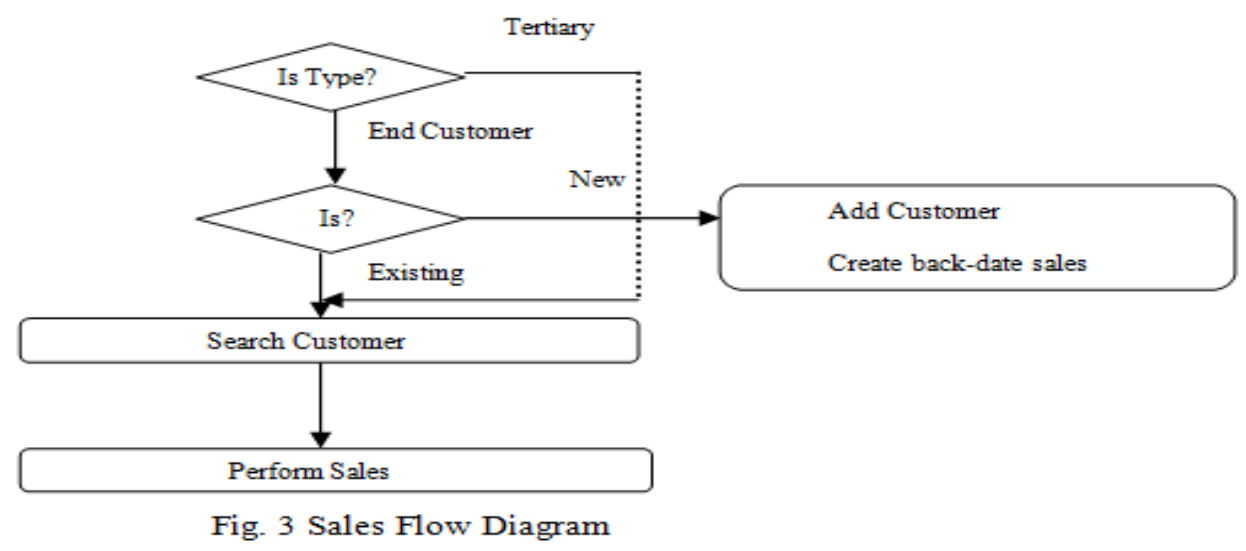




\section{Warranty}

The material or some of its part sold to customer usually fall in warranty period. In case of any damage the customer can get it repaired free of cost, within the warranty period. In below Fig. 4, algorithm for product warranty is explained.

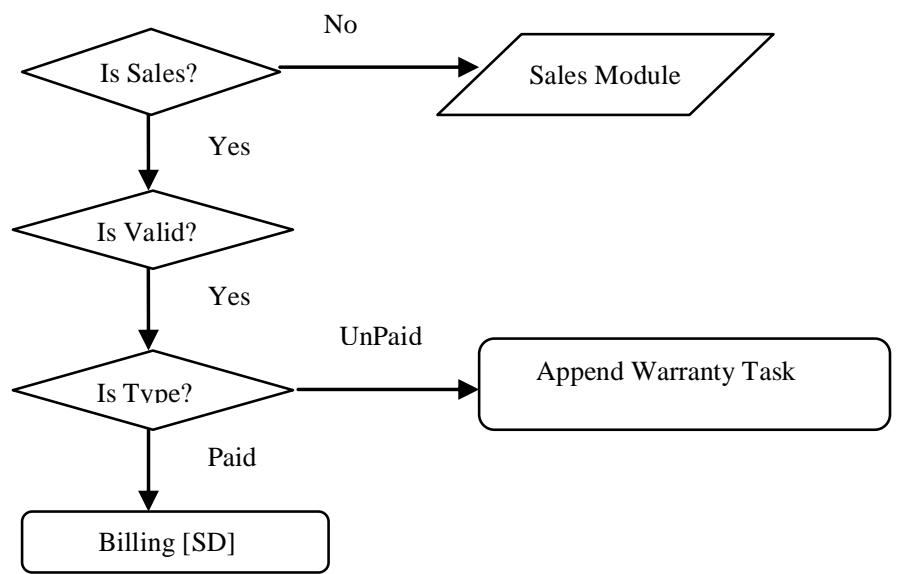

Fig. 4 Warranty Flow Diagram

\section{Service}

Almost quite a number of manufacturers provide servicing facility for the material sold to the end-customer. Usually limited number of times the servicing is provided free of cost to the customer for the material sold falling in servicing period. In below Fig. 5, algorithm for product servicing is explained.

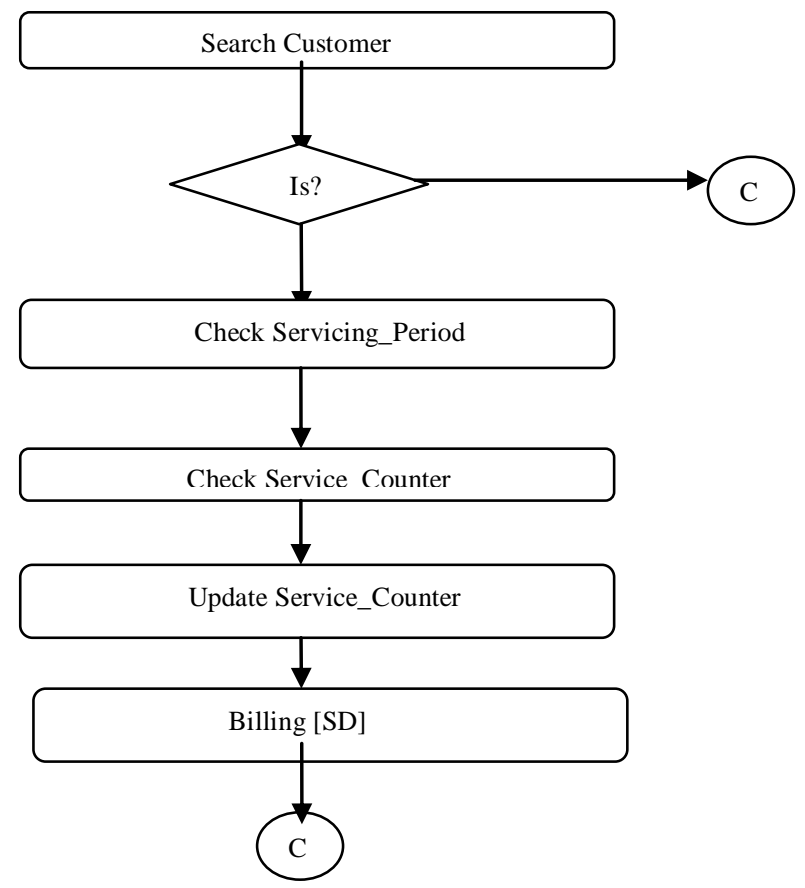

Fig. 5 Service Flow Diagram

\section{Claim}

Whenever a product/material is launched the dealer can claim it based on the criteria of price drop or secondary sales. The dealer must upload excel file providing details grounding behind his claim. In below Fig. 6, algorithm for product claim is explained. 


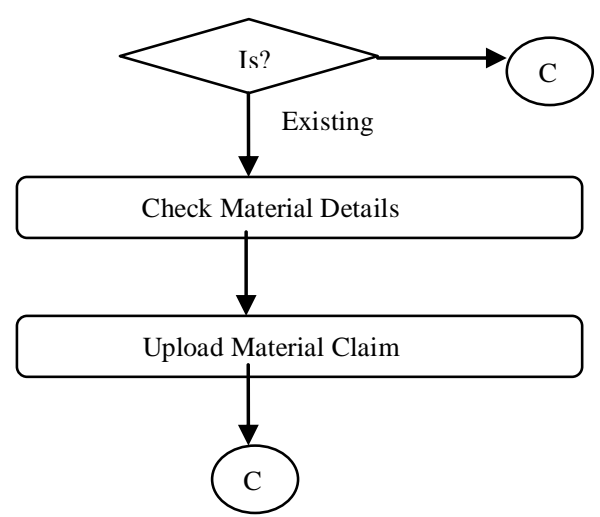

Fig. 6 Claim Flow Diagram

\section{Auction, Bidding \& Revise-Bidding}

Whenever a product/material is launched the manufacturer's prime aim is to set huge market i.e. attract maximum possible buyers for the product. The SDP model proposes to aid manufacturer by creating online auction of the material at a floor price and floor quantity. Once the auction is posted on the website, the dealers can place bid on the product mentioning bid price and bid quantity. Among several bid transactions average bid is selected and material is sold out to respective dealers. Accordingly, if there are dealers who had floor price or floor quantity above selected bid then they are offered more quantity by the manufacturer under the category of revise bidding. In below Fig. 7, algorithm for product claim is explained.

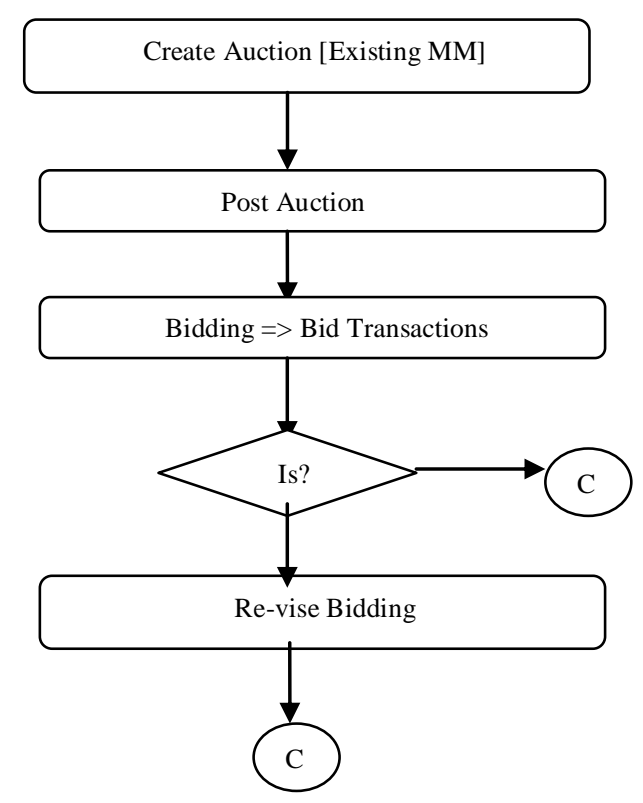

Fig. 7 Auction, Bidding \& Revise Bidding Flow Diagram

\section{Significance}

There are several factors which contribute to the significance of an enterprise solution. We have come up with an efficient and strategic online management for manufacturer's to optimize their business operations with their respective dealers. It is easy to implement and to understand. Table 1 shows some significance of the proposed system. 
An Efficient Framework For Online Dealer Management Portal Using Sap Abap Web

Table 1 Significance

\begin{tabular}{|c|c|c|c|c|c|}
\hline Basis & $\begin{array}{c}\text { Customer } \\
\text { Management }\end{array}$ & Material Management & $\begin{array}{l}\text { Promotional } \\
\text { Schemes }\end{array}$ & Warranty \& Claim & $\begin{array}{l}\text { Sales and } \\
\text { Distribution }\end{array}$ \\
\hline $\begin{array}{l}\text { Customer } \\
\text { Management }\end{array}$ & $\begin{array}{l}\text { From dealer to } \\
\text { tertiary to end } \\
\text { customer track } \\
\text { customer }\end{array}$ & $\begin{array}{l}\text { From dealer to tertiary } \\
\text { to end customer track } \\
\text { material flow }\end{array}$ & $\begin{array}{l}\text { Based on } \\
\text { quantity } \\
\text { demanded by a } \\
\text { manufacturer } \\
\text { can introduce } \\
\text { promotional } \\
\text { schemes as } \\
\text { motivation }\end{array}$ & & \\
\hline $\begin{array}{c}\text { Material } \\
\text { Management }\end{array}$ & $\begin{array}{l}\text { Dealer or } \\
\text { tertiary dealer } \\
\text { sales and } \\
\text { distribution } \\
\text { frequency }\end{array}$ & $\begin{array}{l}\text { Find out material } \\
\text { demand/performance } \\
\text { in each sales division }\end{array}$ & $\begin{array}{l}\text { The product } \\
\text { which is likely } \\
\text { to face tough } \\
\text { competition } \\
\text { with other } \\
\text { manufacturer } \\
\text { requires sales } \\
\text { boosting which } \\
\text { can go for } \\
\text { bidding }\end{array}$ & $\begin{array}{l}\text { Product } \\
\text { performance based } \\
\text { on its health } \\
\text { during warranty } \\
\text { period can be } \\
\text { judged }\end{array}$ & \\
\hline \multicolumn{6}{|l|}{$\begin{array}{l}\text { Promotional } \\
\text { Schemes }\end{array}$} \\
\hline $\begin{array}{l}\text { Warranty \& } \\
\text { Claim }\end{array}$ & & & & $\begin{array}{l}\text { Due to price drop } \\
\text { or secondary sales } \\
\text { claim upload aids } \\
\text { to better prevent or } \\
\text { take appropriate } \\
\text { strategic action of } \\
\text { the product }\end{array}$ & \\
\hline $\begin{array}{l}\text { Sales and } \\
\text { Distribution }\end{array}$ & & $\begin{array}{l}\text { Data for each sales } \\
\text { division can be easily } \\
\text { managed which could } \\
\text { prevent huge amount } \\
\text { of redundancies, } \\
\text { inconsistencies and } \\
\text { customer gets more } \\
\text { flexibility with regard } \\
\text { to product usage } \\
\text { across globe. }\end{array}$ & & & $\begin{array}{l}\text { From excel } \\
\text { upload by } \\
\text { dealer to } \\
\text { database } \\
\text { insert no } \\
\text { manual } \\
\text { interruption } \\
\text { could speed } \\
\text { up and } \\
\text { smoothens } \\
\text { the business } \\
\text { operations }\end{array}$ \\
\hline
\end{tabular}

\section{CONCLUSION}

Today's growing businesses require strategic management for their dealers to be carried out from anywhere at any time in a synchronized way to increase profitability from expensive ERP software solutions. The "Dealer Portal" is SAP based which is designed for such manufacturers to carry out their multiple dealer interaction, upload and manage his/her stock online. It is aimed to extend business experience and opportunities by optimizing sales and distribution.

\section{REFERENCES}

[1] Ezine Articles. "Ezine Articles" What is SAP? An In-depth Definition of SAP ERP System. $30 \quad$ Jan. $2013 . \quad<$ http://EzineArticles.com/1314218>.

[2] C1 India. "Dealer Portal" Dealer Portal Is A Very Simple Yet Comprehensive Buyer - Seller B2b Platform.2 Feb. $2013 .<$ http://www.c1india.com/dealer.html>.

[3] Code Project. "Code Project" Simple Example of MVC. 2 Feb. 2013. < http://www.codepro ject.com/Articles/25057/SimpleExample-of-MVC-Model-View-Controller-Design>.

[4] IT Toolbox. "Enterprise Solutions" An Example of Frameworks. 5 Feb. 2013. < http://it.toolbox. com/blogs/enterprise-solutions/anexample-of-frameworks-21190> 


\section{Author's Profiles}

Manisha Madhwani obtained her BA from University of Allahabad with Advanced National Level Diploma in Computer Applications from National Institute of Electronics and Information Technology and currently pursuing Postgraduation in Masters Of Computer Application (MCA) in Department of Computer Science, Christ University, Bangalore. Her projects includes "One Pass Assembler For 8085 Using Java", "FMCG Online Management Store" and "iBook Management Store". Her research interests include artificial intelligence, robotics and algorithm analysis and design.

Prof. Roseline Mary. R currently serves as an Assistant Professor of Computer Science at Christ University, Bangalore. She obtained her B. Sc( Mathematics) and MCA from Bharathidasan University, M. Phil from Alagappa University and M. Tech from Karnataka State Open University. Her research interests include Programming Languages, Data Mining, and Big Data. 